\title{
Bacteriocins: Molecules of Fundamental Impact on the Microbial Ecology and Potential Food Biopreservatives
}

\author{
Evandro Leite de Souza ${ }^{1 *}$, Clemilson Antonio da Silva ${ }^{2}$ and Cristina Paiva de Sousa ${ }^{1}$ \\ ${ }^{I}$ Departamento de Nutrição; Centro de Ciências da Saúde; Universidade Federal da Paraíba; Brasil. ${ }^{2}$ Programa de \\ Pós-graduação em Ciência e Tecnologia de Alimentos; Centro de Tecnologia; Universidade Federal da Paraíba; \\ $P B$ - Brasil
}

\begin{abstract}
Bacteriocins are proteic molecules synthesized for various lineages of Gram-positive and Gram-negative bacteria when exposed to stressful conditions. Bacteriocins have been characterized as molecules of high antimicrobial property even at low concentrations, provoking the microbial survival inhibition by antibiosis. These substances have their synthesis mediated for genetic mechanisms and develop their lethal action on the microbial cell by multiples mechanisms that can act of isolated or concomitant way culminating with microbial cell killing. This molecules class presents characteristic of stability to heat, low pH, refrigeration and freezing, and resistance to weak organics solvents, salts and enzymes. On the other hand, they are very sensitive to proteolytic enzymes action. Bacteriocins could appear as potential agents to be applied in food conservation systems in order to provide microbiologically stable foods.
\end{abstract}

Key words: Bacteriocins, Antimicrobials, Food Industry, Biopreservation.

\section{HISTORICAL ASPECTS}

At the end of the XIX century, Pasteur and Joubert reported the occurrence of antagonistic interactions among bacteria. These researchers observed that a bacterial isolate was able to interfere on the Bacillus antrachis growth (Jack et al., 1995). At the same way, inhibitory action exerted by a Staphylococcus spp. isolate when in interaction with Corynebacterium diphyteriae was also observed. This discovery led, at that time, the application of Staphylococcal isolates as useful procedure to be applied in diphtheria treatment and this therapeutic use was made by steamer form (Florey, 1996). Gátia (1925) first elucidated the inhibition mechanisms occurring in these processes of microbial interactions. It was observed that $E$. coli cells produced in liquid medium a substance stable to temperature oscillations and also possessors of inhibitory activity on the growth of other taxonomically similar microorganisms. It was, probably, the initial step for studies involving bacteriocins (Jack et al., 1995). Originally, these substances were denominated colicins, because most of the studies observed their synthesis by E. coli cells. After verifying that the synthesis of these molecules was common among other bacteria, it was chosen the name bacteriocin to designate them (Jacob et al., 1953). Bacteriocins have been detected in all major lineages of Eubacteria and Archaebacteria (Torrebranca et al., 1995). 


\section{CHARACTERIZATION SYNTHESIS}

Bacteriocins have been designated as bacterial substances with capacity of inhibiting, even in low concentrations, the multiplication of other bacteria taxonomically similar (Stainer et al., 1986; Brock, 1995). They have formed a heterogeneous group about the producing-bacterial species, molecular size, antibacterial spectrum, stability, physical and chemical properties, and action mode (Davidson and Hoover, 1993; De Vuyst and Vandame, 1994). They also can be designated as antibiotics by definition, even presenting some differences about their applications and clinical effects (Table 01) (Klement et al., 1990; Kuryolowcz, 1991; Davis, 1999). Bacteriocins are one of the most abundant and diversified molecules with antibiotic activity produced by different bacterial genera including Gram-positive and Gram-negative species (Riley, 1998).

Table 1 -Characteristic aspects of bacteriocins and other conventional antibiotics.

\begin{tabular}{|c|c|c|}
\hline Characteristics & Bacteriocins & Other antibiotics \\
\hline Application & foods & clinical \\
\hline Synthesis & ribossomally & Secondary metabolism \\
\hline Activity & limited spectrum & wide spectrum \\
\hline $\begin{array}{l}\text { Presence of immune cells in the host } \\
\text { Action mode }\end{array}$ & $\begin{array}{c}\text { present } \\
\text { the most through the channel } \\
\text { formation in the cell cytoplasmic } \\
\text { membrane }\end{array}$ & $\begin{array}{c}\text { absent } \\
\text { specific target }\end{array}$ \\
\hline $\begin{array}{l}\text { Toxicity/other effects in eukaryotic } \\
\text { cells }\end{array}$ & absent & present \\
\hline
\end{tabular}

Antibiotic designates all substance originated from microorganisms, animals, plants or through the synthetic way that at low concentrations must have the following properties: i) lethal or inhibitory activity against microbial species; ii) ability to prevent the appearance of microbial resistance; iii) absence of undesirable effects to the host; and iv) chemical stability (Tavares, 1984; Amato Neto et al., 1994; Abrahan et al., 1996). In general way, antibiotics can be defined as agents of great interference on the growth and/or microbial activities (Trabulsi et al., 2002). Substances recognized as antibiotic exert their activity by different ways that act on diverse targets in/on the microbial cell. It includes: i) damaging the cell wall; ii) destabilizing the cytoplasmic membrane; iii) changing the nucleic acid structure; iv) inhibiting the enzymatic action; v) antimetabolic action; and vi) affecting the acid nucleic synthesis (Pelczar et al., 1980).

Looking for nutrients and space for multiplication, some bacteria secrete ribossomally synthesized polypeptides (bacteriocins) that cause selective death of competitor microorganisms (Tadashi and Schnneewind, 1998). Surveys have showed that bacteriocins synthesis is encoded by genes located in plasmids (for example, Col plasmid in E. coli lineages) differently of other antibiotic compounds that generally are derivated from secondary metabolism (Ker and Tate, 1984; Hancock and Chapple, 1999; Trabulsi et al., 2002). Genetic determinants of many of these molecules have been also identified. Some are related with plasmids of different sizes, as pediocinin produced by Pediococcus and lactocin produced by Lactococcus lactis. Some are related to chromosomes, as plantaracin A and sakacina 674, while other are related to transpossons, as nisin produced by L. lactis (Ray, 1996).

Structural gene location, in other words, the codification gene involved in the synthesis of many bacteriocins, has been also established. Generally, these structural genes are located in an operon, which is directly involved in the processing and transport of ones through the prokaryotic cytoplasmic membrane (Jack et al., 1995). Bacteriocin molecule is transported through the bacterial cell as inactive peptide containing a $\mathrm{N}$-terminal leader and a C-terminal propeptide. The leader portion is removed by specific peptidases with consequent its activation, being followed for excretion of the active molecule in 
the environment. However, some bacteriocins at $\mathrm{pH} 5.0$ and above remain adsorbed on the producing-cell surface. These molecules have a positive charge and present the tendency to form aggregates (Klaenhamer, 1993).

\section{MOLECULAR ASPECTS}

Many surveys involving bacteriocins study have been addressed to understand their general molecular characteristics. These molecules present generally proteic nature, varying of low molecular weight polypeptides as those synthesized by phytopahtogenic Corynebacterium species, until great proteic molecules as those synthesized by Pseudomonas seringae (Gross and Vidaver, 1979; Stainer et al., 1986; Klement et al., 1990). They are still characterized as cationic and hydrophobic substances, some them presenting a disulfide bridge in their molecular structure. Most of the ones presents as small molecules, with 50 or less aminoacids. Nisin, most studied bacteriocin, has 35 aminoacids. There are 44 in pediocin $\mathrm{AcH}$ produced by Pediococcus acidilactic, 43 in sakacin produced by Lactobacillus sake LB 706, 37 in lactacin produced by Lactobacillus lactis subsp. cremosis 9B4 (Daeschel, 1989; Daeschel and Ray, 1992; Klaenhammer, 1993). These molecules have stability to heat, low $\mathrm{pH}$, refrigeration and freezing, and also to various weak organics solvents, salts and enzymes. On the other hand, they are sensitive to proteolytic enzymes (Ray, 1996).

\section{ACTION MODE}

Bacteriocins biological action occurs through the specific receptors located on the target microbial cell surface. After binding with these receptors, various mechanisms act, by isolated or concomitant way, causing the microbial cell killing (Paker et al., 1989; Daw and Falkiner, 1996; Brashears et al., 1998). Bacteriocins are powerful toxins, often very specific, and usually produced during the exposition of some bacterial lineages to stressful conditions. When released in environment cause quick elimination of no immune or no resistant neighboring microbial cells to their action (Tadashi and Schnneewind, 1998).
Antagonist action exerted by bacteriocin producing-bacteria on other bacteria inserted in the same environment is defined as antibiosis (Hayes, 1993). Antibiosis occurs when two or more microorganisms present in an environment could adversely interfere on the growth and survival of other ones (Ray, 1996). Competition for essential nutrients, accumulation of D-aminoacids, lowering of oxidation-reduction potential and coagregation may be involved in antagonism (Schillinger, 1990; Sinell, 1989). Microbial cell killing due bacteriocins action could occur as consequence of unbalanced cytoplasmic membrane function (affecting energy synthesis and permeability), inhibition of nucleic acid synthesis, interference on the protein synthesis and changing cell translator mechanism. There are still some bacterial lineages that could suffer cell lyse (Daw and Falkiner, 1996). Bacteriocin producing-cells are not affected by action of bacteriocin due to the development of specific immunity mediated by a protein (Hancock and Chapple, 1999). Once secreted and activated, the bacteriocin has remarkable property of detection and causing death to the competitor bacteria, while provoke little or no damage to its producing-cell (Tadashi and Schinneewind, 1998). Bacteriocins are normally effective against Grampositive bacteria belonging to different genera and closely related species (Ker and Tate, 1984, Moreno et al., 2000). Nisin end pediocin AcH are examples of bacteriocins owner of prominent antimicrobial spectrum which are able to exert inhibitory activity on the growth of bacteria such as Lactobacillus plantarum, Pediococcus acidilactici, Leuconostoc mesenteroides, Listeria monocytogenes and Micrococcus luteus (Ray, 1996).

It has been considered as competitive superiority when microorganisms dispute ecological niches in the environment where they are developing their metabolic activities (Stockewell et al., 1993). Regarding their narrow action, bacteriocins primary role is as intra-specific mediators or promoters of interactions among microbial populations (Cleeveland et al., 2001).

\section{COLICINS}

Colicins, bacteriocins produced by E. coli cells, had been focus of several ecological studies involving microorganisms (Paker et al., 1989; Gordon and Riley, 1999). When in stressful 
conditions, such as nutrients depletion or overpopulation. E. coli cells inserted in a microbial population and able to synthesize colicins are induced to synthesize them. These molecules are released in the environment generally through the producing-cell lyses. After that, binding between colicin and surface receptors located on the target bacterial cell occurs, followed by transport into the target bacterial cell and provoke bacterial death by three primary mechanisms: i) forming channels in the plasmatic membrane; ii) degrading DNA; and iii) inhibiting the proteic synthesis (Prado et al., 2000).

Recognition and colicins transport are highly specific mechanisms able to provoke lethal action only on E. coli cells. On the other hand, colicins have very low inhibitory action on other enteric bacteria. Colicin resistance occurrence among Enterobacteriaceae family representatives suggest that these molecules act mainly in intra-specific way. Levels of resistance to colicin action among enteric bacteria are as high as or higher than levels detected within of $E$. coli population (Tadashi and Scheennewind, 1998). Colicins producing-cells synthesize an auto-immune protein that provides protection or immunity to the bacteriocin produced by themselves. This protein is encoded in an operon (Figure 1). Once recognized the bacteriocin, a binding between the immune protein and the colicin C-terminal portion occurs and this protect the producing-cell killing (Ray, 1996). The mechanism of development of resistance intermediated by auto-immune protein could involve some alterations in the cellular surface receptors. These receptors are used by colicins like structures of access for the target cell inside. This mechanism is recognized as true resistance. Other kind of development of survival mechanism can occur due a direct change in the transport procedure used by bacteriocin across the target cell cytoplasmic membrane and it is results tolerance development (Cleveland et al, 2001). Only those microbial cells that develop immunity, as well as resistance or tolerance are able to survive under environment conditions produced due the colicin action.

On average about $30 \%$ of the E. coli natural population produce colicins. Over 25 kinds of colicins have been characterized (Tadashi and Schnneewind, 1998). However, every studied microbial population differs for the combination of synthesized colicins, and generally there is one dominant kind among other ones present. Numerous cells in a microbial population are resistant to one or more produced colicins, with an average of $70 \%$ being resistant to some colicin, and $30 \%$ being resistant to all colicins produced (Gordon and Riley, 1999). In a natural microbial population occurs there a constant flux along time in the relative frequency of $E$. coli cells which are able to produce colicins, as well as of resistant and sensitive cells to the colicins action (Riley, 1998).

\section{BACTERIOCINS AS POTENTIAL FOOD BIOPRESERVATIVES}

In the food production it is crucial that suitable actions are taken to guarantee the safety and stability during the food shelf-life. In particular, the current trends adopted by modern consumer and food legislation have made this aim a great challenge for the food industry (Brull and Coote, 1999). Nowadays, the consumers require foods of high quality, without chemical preservatives, safe and possessing long shelf-life. Concomitantly, the food legislations have restricted the use of some chemical preservatives in different foods (Brull and Coote, 1999). These have caused many problems for the food industry (Piper et al., 1998). Nowadays, there are discussions concerning the new antimicrobial agents able to be applied in food conservation systems. These agents could be used through the combination of various under lethal treatments and could provide the necessary protection to the food against pathogen and spoilage microorganisms (Peck, 1997). Similarly, a new perspective of food conservation emphasizes the application of the named "natural antimicrobial system", where could use the synergistic action of several elements. It includes the animal, microbial and plant products having antimicrobial properties, jointly with physical nature procedure, packaging procedures, manufacture procedures, and the storage food procedures. These actions in an associated use could produce a synergistic effect able to propitiate an unfavorable environment to the microbial survival (Gould, 1995). This possibility has received great emphasis and generates a pressure on the food industry to adopt natural alternatives to achieve its aims related to food conservation (Brul and Coote, 1999). 


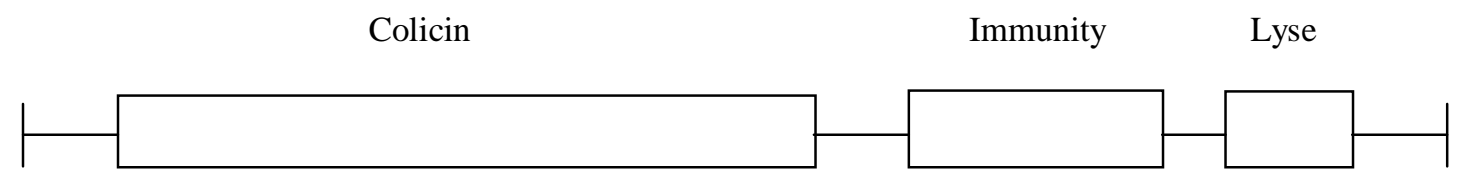

Figure 1 - Colicins are encoded in an operon. Generally, this operon comprehends three genes intimately linked: i) a colicin codifier gene, which functions as competitor cells killer; ii) a immunity codifier gene, which encoded the synthesis of a protein able to confer for the producer cell a specific immunity front the colicin action; iii) and a lyses gene, which encoded the synthesis of a protein able to provoke the producing-cell lyses. It exerts function of releasing the colicin in the environment where is inserted the microbial population. These genes are located in an operon, and are encoded by plasmid replication process in E. coli cell (Gordon and Riley, 1999).

Searching new technologies to be applied for food conservation, the use of substances produced by microorganisms deserve prominence. Among these substances, bacteriocins deserve special attention (Daw and Falkiner, 1996). These molecules are included in occurring preservatives class and biological molecules of low molecular weight subclass (Brul and Coote, 1999). Lactococcus, Streptococcus, Leuconostoc, Pediococcus, Bifidobacterium and Propionibacterium species used in the food fermentation are admittedly bacteriocins producer. Many of these bacteriocins should have their different characteristics studied, which is necessary before their rational use as biopreservatives (Cleveland et al., 2001).

Six general principles must be evaluated for the use of substances as food additives: i) all proposed additives must be toxicologically tested and evaluated in all pertinent aspects, including accumulative, synergistic and potential effects; ii) only those additives considered safe in the intended level of insertion must be released to use; iii) all food additives must be again evaluated when arisen new information about their use and safety; iv) food additives must always be kept in conformity as specifications approved by Codex Alimentarius Commission; v) the justification of the additives use must be based strongly in the requisites of food safety of different characters of consumers, and it also must present as economically and technically feasible alternative; vi) the temporary or permanent approval of use of a food additive must consider the limitation for specific foods, the purpose, use conditions, decrease of necessary level to reach the desirable effects and the acceptable daily intake for human, and still must consider the probable intake of special consumers (Concon, 1980).

Some bacteriocins have well established their action as potential antimicrobial and also their possible applications in food preservation systems. Nisin A already showed effective inhibitory activity on the Listeria monocytogenes growth in cheese along eight weeks. Enterocin, when inoculated in ham, pig meat, meat chicken, and sausage, showed inhibitory capacity on the $L$. monocytogenes growth. Lactocin also had inhibitory capacity on the same microorganism, when applied in ground meat (Vignolio et al., 1996; Davies, 1999; Aymerich et al., 2000). There are numerous applications of nisin as food preservative, including shelf-life extension of dairy products, canned foods, vacuum-packed meat and cold smoke salmon (Hurst, 1981; Davies, 1999; Nilsson et al., 2000).

Nisin presents as desirable characters: i) toxicity absence; ii) naturally produced by Lactococcus lactis; iii) heat stability; iv) storage stability; v) degradation by digestive enzymes; vi) not conferrer undesired taste and flavor to foods; and vii) prominent antimicrobial spectrum against Gram-positive microorganisms (Kominsky, 1999; Fiorentini et al., 2001). But, it is less active to inhibit most of Gram-negative bacteria, yeast and moulds (Harris et al., 1997).

Although bacteriocins antimicrobial role has been recognized it is still used a little in food conservation. Probably, due the absence of detailed studies of their particularities. Among the major bacteriocins, nisin, acidocin, bavaracin, curavaticin, sakacin, although recognized, are not well characterized. Nisin is the single bacteriocin commercially used as natural agent of food conservation (biopreservation) and considered safe 
by World Health Organization (WHO) and has received the denomination of Generally Recognized as Safe (GRAS) and also by Food and Drug Administration (FDA). Nisin is produced by Lactococcus lactis subsp. latis and is used in various countries (Abee et al., 1994). Diplococcin, lactostrepcin, lactococcins, dricin, lacticin are other bacteriocins also produced by $L$. lactis (Moreno et al., 2000).

Nisin inhibitory action on Gram-positive microorganisms occurs through the two stages. First, involves an unspecific interaction between the nisin and the target microbial plasmatic membrane, which is characterized as reversible and $\mathrm{pH}$-dependent phenomenon. During the second stage, there occur a strong attraction of the nisin with the target citoplasmic membrane, where late on channels of diameter 0.1 to $0.2 \mu \mathrm{m}$ are formed. The simultaneous membrane depolarization provokes a quick flux of essential molecules $\left(\mathrm{K}^{+}\right.$ions, aminoacids, ATP), leading to alterations that culminate with the cellular lyses (Liu and Hansen, 1990).

\section{CONCLUSIONS}

The possible use of bacteriocins as food biopreservatives could lead to the replacement of synthetic chemical preservatives, which have their antimicrobial action reduced due the continued appearance of multiresistant microbial lineages. The increasing occurrence of classic and/or emerging food borne diseases and it is possibly related to the indiscriminate use of chemicals preservatives favoring the selection of microbial lineages more and more resistant, and therefore of difficult control. Bacteriocins are agents that could act on the microbial cell through different ways when compared to conventional chemical food preservatives, provoking the formation of an inhospitable environment to microbial survival. In addition, these molecules present characteristics of resistance to heat, acidity, low water activity and oscillations of temperature. However, there is the necessity to develop studies involving the establishment of the some bacteriocins characteristics, such as: i) antimicrobial spectrum; ii) isolation; iii) toxicity; iv) stability; and v) techno-economic viability of their use as control agents to the growth and microbial survival in foods.

\section{RESUMO}

Bacteriocinas são moléculas protéicas sintetizadas por várias linhagens de bactérias Gram-positivas e Gram-negativas quando submetidas a condições de stress. São ainda caracterizadas como moléculas de alto poder antimicrobiano mesmo em baixas concentrações, provocando a inibição da sobrevivência microbiana através de uma ação de antibiose. As bacteriocinas têm seu processo de síntese mediado por mecanismos genéticos, e desenvolvem sua ação letal sobre a célula microbiana por intermédio de múltiplos mecanismos que podem agir de forma isolada ou concomitante culminando com a morte da célula microbiana. Estas moléculas apresentam características de estabilidade ao calor, baixo $\mathrm{pH}$, refrigeração, congelamento, resistência a ácidos orgânicos fracos, sais e enzimas, porém são muito sensíveis à enzimas proteolíticas. Assim, as bacteriocinas podem aparecer como potenciais agentes para serem aplicados em sistemas de conservação de alimentos com objetivo de prover alimentos microbiologicamente estáveis.

\section{REREFERENCES}

Abee, T.; Romboust, F. M.; Hungenhaltz, J.; Gruhard, G. and Letellier, L. (1994), Mode of action of nisin Z against Listeria monocytogenes scott a grawn at high and low temperatures. Applied and Environmental Microbiology, 60, 1962-1968.

Abrahan, A. M. L.; Gomez, A. L. B. and Andrew, C. F. (1996), Aislamento de dermatófitos a partir de niños sin signos clínicos de dermatofitoses. Revista Cubana de Medicina Tropical, 38,147-150.

Amato Neto, V.; Levi, G. C. and Lopes, H. V. (1994), Antibióticos na Prática Médica. São Paulo : Roca.

Aymerich, T.; Garriga, M.; Ylla, J.; Vallier, J.; Monfort, J.M. and Hugas, M. (2000), Effect of sausage ingredients and additives on the production of enterocin A and B by Enterococcus faecium CT492. Optimization of in vitro production and anti-listerial effect in dry fermented sausages. Journal of Applied Microbiology, 88, 686-694.

Brashears, M.; Reilly, S. and Guilland, S. E. (1998), Antagonistic action of cells of Lactobacillus lactis toward E. coli O157:H7 on refrigerated raw chicken meat. Journal of Food Protection, 61,166-179.

Brock, T. D. (1995), Biology of Microorganisms. New Jersey : Prentice Hall. 
Brul, S. and Coote, P. (1999), Preservatives agents in food: mode of action and microbial resistance mechanisms. International Journal of Food Microbiology, 50, 1-17.

Cleeveland, J.; Mantiville, T. J.; Ness, I. F. and Chiknids, M. L. (2001), Bacteriocins: safe antimicrobials for food preservation. International Journal of Food Microbiology, 71,1-20.

Concon, J. M. (1980), Food Toxicology: contaminants and additives (part B). Marcel Deker Inc., New York

Daeschel, M.A., (1989) Antimicrobial substances from acid latic bacteria for use as food preservative. Food Technology, 43,164-167.

Daeschel, M. A. and Ray, B. E. (1992), Food Biopreservatives of Microbial Origin. Boca Raton : CRC Press.

Davidson, P. M. and Hoover, D. G. (1993) Antimicrobial components from latic acid bacteria. In: Salminen, A. Von Wright, A. (Eds.). Latic acid bacteria. New York : Chapman \& Hall. pp.127-150.

Davies, E. A. (1999), Effective use of nisin to control lactic acid bacterial spoilage in vacuum-packed bologna-type sausage. Journal of Food Protection, 9, 1004-1010.

Davis, I. (1999), What are antibiotics? Archaic functions for modern activities. Molecular Microbiology, 4, 1227-1232.

Daw, M. A. and Falkiner, F. (1996), Bacteriocins: nature, functions and structure. Micron, 27, 467-479.

De Vuyst, L. and Vandame, E. J. (1994) Bacteriocins of latic acid bacteria. Microbiology, genetics and application. New York : Chapman \& Hall.

Fiorentini, A. M.; Ernani, S. S.; Porto, A. C. S.; Jaciara, Z. M. and Franco, B. D. G. M. (2001), Influence of bacteriocins produced by Lactococcus plantarum $\mathrm{BN}$ in the shelf-lie of refrigerated bovine meat. Brazilian Journal of Microbiology, 32, 42-46.

Florey, H. W. (1996), The use of microorganisms for therapeutic e structure. Micron, 27,467-479.

Gordon, D. and Rilley, M. A. (1999), The ecological role of bacteriocins in bacterial competition. Trends in Microbiology, 7, 129-133.

Gould, G. W. (1995), Industry perspective on the use of natural antimicrobial and inhibitors for food applications. Journal of Food Protection, 35, 82-86.

Gross, D. C. and Vidaver, A. K. (1979), Bacteriocins of phytopatogenic Corynebacterium species. Canadian Journal of Microbiology, 25, 367-347.

Hancock, R. E. and Chapple, D. S. (1999), Peptides antibiotics antimicrobial. Agents in Chemotherapy, 43, 1317-1323.

Harris, L. J.; Fleming, H. P. and Klaenhammer, T. R. (1997), Development in nisin research. Food Research International, 25, 57-66.

Hayes, P. R. (1993), Microbiologia e Higiene de los Alimentos. Zaragoza : Acribia.

Hurst, A. Nisin. (1981), Applied Microbiology, 27, 85-122.
Jack R. W.; Tagg, J. R. and Ray, B. (1995) Bacteriocins of gram-positive bacteria. Microbiology Reviews, 59, 171-200.

Jacob, F.; Lwaff, A.; Siminonvich, A. and Wallman, E. (1953), Definition de qualques terms relatifs à la lysogenie. Annales de Institut Pasteur, 84, 222-224.

Ker, A. and Tate, M. E (1984), Agracins and biological and control of craw gall. Microbiology Science, 1, 1-14.

Klaenhammer, T. R. (1993), Genetics of bacteriocins produced by latic acid bacteria. FEMS Microbiology Reviews, 12, 39-45.

Klement, Z.; Rodolph, K. and Sands, D. C. (1990), Methods in phytobacteriology. Buldapeste : Akadímiai Kiado.

Kominsky, G. M. R. (1999), Avaliação da sensibilidade de microrganismos selecionados a diferentes concentrações de nisina em salsichas comuns e de frango. Higiene Alimentar, 13, 56-62.

Kurylowcz, L. (1991), Antibióticos - uma visão crítica. Recife : Ed. Universitária-UFPE.

Liu, W. and Hansen, J. N. (1990), Some chemical and physical properties of nisin, a small-protein antibiotic produced by Lactococcus lactis. Applied and Environmenalt Microbiology, 56, 2551-2558.

Moreno, I.; Learyer, A. L. S. and Leitão, M. F. (2000), Detection and characterization of bacteriocins producing of Lactobacillus lactis strains. Brazilian Journal of Microbiology, 31, 184-192.

Nilsson, L.; Chen, Y.; Chikindas, M. L.; Huss, H. H.; Gran, L. and Monteville, T. J. (2000), Carbon dioxide and nisin act synergistically on Listeria monocytogenes. Applied and Environmental Microbiology, 66, 769-774.

Paker, M. W.; Pattus, F.; Tucker, A. D.; and Tsernoglou, D. (1989), Structure of the membrane forming fragment of the colicin A. Nature, 37, 93-96.

Peck, M.W. (1997), Clostridium botulinium and the safety of refrigerated processed foods of extended durability. Trends in Food Science and Technology, 8, 186-192.

Pelczar, M.; Reid, R. and Chan, E. C. S. (1980), Microbiologia. São Paulo : McGraw-Hill.

Piper, P. W.; Thompson, S.; Pandajaint, R.; Holyoak, C.; Egner, R.; Muhlbauer, M.; Coote, P.; Prado, C. S.; Santos, W. Z. and Carvalho, C. R. (2000), Atividade antimicrobiana de bactérias láticas isoladas em embutido curado frente Listeria monocytogenes. Arquivos Brasileiros de Medicina Veterinária e Zootecnia, 53, 417-423.

Ray, B. (1996), Fundamental food microbiology. Washington : CRC Press.

Riley, M. A. (1998), Molecular mechanisms of bacteriocins evolution. Annals in Reviewed Genetic, 32, 255-278.

Sinell, H. J. (1989), Interacting factors affecting mixed populations. In: Silliker, J. H. Microbial Ecology of Foods. New York : Academic Press. pp.215-240. 
Schillinger, U. (1990), Bacteriocins of latic acid bacteria. In: Bills, D. D. and Kung, S. (Eds.). Biotechnology and Food Safety. Boston : Butterworth-Heinemann. pp. 55-74.

Stainer, R. U.; Ingraham, J. L.; Wheelsis, M. L. and Pairtes, P. R. (1986), The Microbial World. New Jersey : Prentice Hall.

Stockewell, V. O.; Moore, L. W. and Looper, J. E. (1993), Fat of agrobacterium radiobacter K84 in the environment. Applied and Environmental Microbiology, 59, 2112-2120.

Tadashi, B. and Schnneewind, O. (1998), Instruments of microbial warfare: bacteriocin synthesis, toxicity and immunity. Trends in Microbiology, 6, 66-71.

Tavares, W. (1984), Manual de Antibióticos. São Paulo : Atheneu.

Torrebranca, M.; Meseguer, I. and Ventosa, A. (1995), Bacteriocin biology. Letters in Apllied Microbiology, 19, 201-205.

Trabulsi, L. R.; Alterthum, F.; Gompertz, O. F. and Candeias, J. A. N. (2002), Microbiologia. Atheneu, São Paulo.

Vignolio, G.; Fadda, S.; Kairuz, M. N.; Ruizholgado, A. A. and Oliver, G. (1996), Control of Listeria monocytogenes in ground beef by lactocin 705, a bacteriocin produced by lactobacillus casei CRL 705 . International Journal of Food Microbiology, 29, 3997-4002.

Received: February 02, 2004; Revised: October 01, 2004; Accepted: May 23, 2005. 